\title{
DE
}

DE GRUYTER

OPEN

DOI 10.2478 /pesd-2018-0027

PESD, VOL. 12, no. 2, 2018

\section{MAXIMUM VALUES OF FROZEN SOIL'S DEPTH AND HOAR FROST'S THICKNESS ESTIMATED ON THE BASIS OF EXTREME VALUES THEORY}

\author{
Maria Nedealcov ${ }^{1}$, Valentin Răileanu ${ }^{1}$, Gheorghe Croitoru ${ }^{2}$, \\ Cojocari Rodica, Crivova Olga
}

Keywords: GEV and Gumbel distributions, frozen soil, hoar-frost, return period, constructions.

\begin{abstract}
Extreme climatic phenomena present risk factors for agriculture, health, constructions, etc. and are studied profoundly these past years using extreme value theory. Several relation that describe positive extreme values' probability Generalized Extreme Value and Gumbel distribution are presented in the article. As a example, we show the maps of characteristic and reference values of the maximum depth of the frozen soil and thickness of hoar-frost with a probability of exceeding per year equal to 0,02 , which is equivalent to the mean return interval of 50 years. The obtained results could serve as a base for elaboration of national annexes in constructions.
\end{abstract}

\section{Introduction}

Extreme weather events are risk factors for the environment, agriculture, health, road, rail and air transport, construction, etc. These phenomena cause human and material damage and are intensively studied in recent decades using extreme value theory. Global warming has become a reality. There is an intensification and increased frequency of extreme weather events' occurence.

As a result, there is a need to study the temporal and spatial distribution of climatic risk factors, including those in the construction industry. As an example, we present maps of the characteristic (reference) values of the depth of soil frost and hoar frost's thickness with certain return periods.

${ }^{1}$ Institute of Ecology and Geography of the Academy of Sciences of the Republic of Moldova, e-mail: marianedealcov@.yahoo.com

${ }^{2}$ Ministry of Regional Development and Constructions. Republic of Moldova 
Frozen terrain can cause cracks in the building foundation due to increased volume in the process of water transformation into ice (STAS 6054, 1977, СП 20.13330, 2016, ДБН В.1.2-2, 2006 normative documents). Durability depends on the depth of the foundation of the building is determined by taking into account the depth of the frost, the soil-forming rock, the groundwater level, the constructive minimum height of the foundation and technological conditions of the loads exerted on the foundation of the building. The foundation depth can not be less than the maximum freezing depth during the lifetime of the building. When designing roads, the total thickness of the asphalt and the floor must not be less than the maximum freezing depth during exploitation period.

Hoar frost is formed by white, crumbly, snow-like ice crystals, mainly on branches, conductors, corners and edges of objects, usually in frosty weather, in the presence of mist and weak wind.

Hoar frost loads should be taken into account for power lines and air communications, electrified transport contact networks, antenna devices as well as ventilated facades of buildings, metal balconies (CП 20.13330, 2016, ДБН В.1.2-2б 2006, NTE 003/04/00, 2004 normative documents).

The freezing depth of the soil is measured in $\mathrm{cm}$, and the thickness of the hoar frost - in mm.

\section{Materials and research methods}

As initial materials, the annual maximums of frozen soil's thickness and hoar-frost thickness were used for the period of 1961-2016, recorded at the meteorological stations of the State Hydro-meteorological Service. The development of digital maps was performed in ArcGIS 10 by interpolation of the reference values (characteristic) with the mean return period of 50 years, calculated for each meteorological station.

The distribution of maximum climatic values, especially the annual ones, is expressed by the Generalized Extreme Value Distribution (www.mathwave.com):

$$
G(x ; \mu, \sigma, \xi)=\exp \{-[1+\xi(x-\mu) / \sigma]\}^{-1 / \xi},
$$

where $-\infty<\boldsymbol{\mu}<\infty, \boldsymbol{\sigma}>\mathbf{0}$ and $-\infty<\xi<\infty$ are the location, scale, and shape parameters. Depending on the value $\xi$, the expression (1) defines three types of distribution: Weibull $(\boldsymbol{\xi}<\mathbf{0})$, Gumbel $(\boldsymbol{\xi}=\mathbf{0})$ and Frechet $(\boldsymbol{\xi}>\mathbf{0})$.

Majority of european countries use Gumbel distribution (Engineering Statistics Handbook) for evaluation of climatic extremes values in construction 
field, expressed by probability density function (PDF) and cumulative distribution function (CDF):

$$
\begin{gathered}
f(x)=(1 / \sigma) \exp (-z-\exp (-z)) \\
F(x)=\exp (-\exp (-z))
\end{gathered}
$$

where $z=(x-\mu) / \sigma, \mu$, şi $\sigma-$ location and scale (distribution's parameters), $f(x)$ $=d F(x) / d x$.

Distribution's parameters can be expressed by mean $\boldsymbol{x}_{\text {med }}$ and standard deviation $\sigma_{1}$ of the sample: $\boldsymbol{\mu}=\boldsymbol{x}_{\text {med }}-\gamma \boldsymbol{\sigma}$, where $\gamma \approx \mathbf{0 . 5 7 7 2}$-Euler-Mascheroni constant, $\sigma=(\sqrt{ } 6 / P i) \sigma_{1}$. Consequently, $\mu=x_{\text {med }}-0.45 \sigma_{1}$ and $\sigma=0.7797 \sigma_{1}$. 4). function $F(x)$.

Quintile $x(p)$ is the inverse function of the cumulative distribution In Gumbel distribution for maximums quintile is expressed by the relation:

$$
x(p)=\mu-\sigma \ln (-\ln (p))
$$

Consequently, $x(p)=x_{m e d}-\{0.45+0.7797 * \ln [\ln (1 / p)]\} \sigma_{1}$

The reference (characteristic) value to be exceeded in one year with the probability $\mathrm{p}$ is equal to $x(1-p)=x_{\text {med }}-\{0,45+0,7797 * \ln [\ln (1 / 1-p)]\} \sigma_{1}$ (7)

Reference value to be exceeded in one year with probability $p=0,02$ (avergae return period IMR $=50$ years) is equal to $\boldsymbol{x}\left(\mathbf{0 , 9 8 )}=\boldsymbol{x}_{\text {med }}+2.5923 \sigma_{1}(\boldsymbol{8})\right.$

Using relation (8) is the simplest procedure of evaluation of reference values of extremes with average return period of once per fifty years. Relation (7) can be used for calculating the values with other return periods.

There is an extensive range of software which can be used for evaluation of extreme values' parameters distribution: Statgraphics Centurion, Mathlab, Statistica, EasyFit, etc., or modules generating graphs and tables elaborated in $\mathrm{R}$ language.

\section{Obtained results}

As initial data, we had used the maximum annual values of the depth of soil frost in $\mathrm{cm}$, recorded at 17 meteorological stations of the State Hydrometeorological Service between 1961 and 2016 (56 years), with some exceptions (Bălţi - 30 years, Bravicea - 55 stations Cahul - 55 years, Camenca 54 years, Ceadir-Lunga - 55 years, Comrat - 52 years, Corneşti -50 years, Dubăsari - 54 years, Leova - 54 years, Voda - 55 years, Tiraspol - 54 years). 
The maximum annual values are obtained from the maximum values for 5 days or decades for the November-April period.

The mean value and standard deviation of the frozen soil's depth and the Href reference value corresponding to the 50 -year return period according to the equation (8) were calculated for each meteorological station. Href values were spatially interpolated using Spline method (Radial Basic Functions, Minimum Curvature) in ArcGIS. The map of the spatial distribution of frozen soil's depth reference values with the 50-year average return period is shown in Fig. 1.

Href field varies within $60-110 \mathrm{~cm}$ in the field. The corresponding values are indicated on the Href isolines. Average values are observed in the CentralWestern part of the country. Minimal values are characteristic of the South and South East of the country. The highest values are observed in the North and Central-East of the territory. Table 1 presents the reference values extracted from the digital map for 57 cities and municipalities in the Republic of Moldova.

The normative value (9-12) of hoar frost's linear load for cross-sectional elements up to $70 \mathrm{~mm}$ in diameter (wires, cables, bars, pillars, etc.), $i \mathrm{~N} / \mathrm{m}$ must be determined by the formula:

$$
i=\pi b k \mu_{1}\left(d+b k \mu_{1}\right) \rho g 10^{-3}
$$

The normative value of the surface ice load (9-12), $\boldsymbol{i}^{\prime} \mathrm{Pa}$, for the remaining structural elements should be determined by the formula:

$$
i^{\prime}=b k \mu_{2} \rho g
$$

(10),

where $\boldsymbol{b}$ is the normalized thickness of the hoar frost, $\mathrm{mm}$ (exceeded in average once in 5 years), for circular cross-sectional elements with $10 \mathrm{~mm}$ diameter, located at a height of $10 \mathrm{~m}$ above the ground. $\boldsymbol{k}$ is the- the coefficient which takes into account hoar frost's thickness change depending on the height. For $h$ $=10 \mathrm{~m}, \boldsymbol{k}=1.0, \boldsymbol{\mu}_{1}$ is the coefficient which takes into account the change in the thickness of the hoar frost depending on the diameter of the element. For $\boldsymbol{d}=$ $10 \mathrm{~mm}, \mu 1=1,0, \boldsymbol{\mu} 2$ is the coefficient which takes into account the ratio of the surface area of the element subjected to hoar frost accumulation to the entire surface of the element and which equals to 0.6 for objects with small crosssections and for other objects it is based on the special investigation data. $\rho$ is the ice density, $0,9 \mathrm{~g} / \mathrm{cm}$ and $\mathrm{g}, \mathrm{m} / \mathrm{s}$, is the free fall acceleration. 


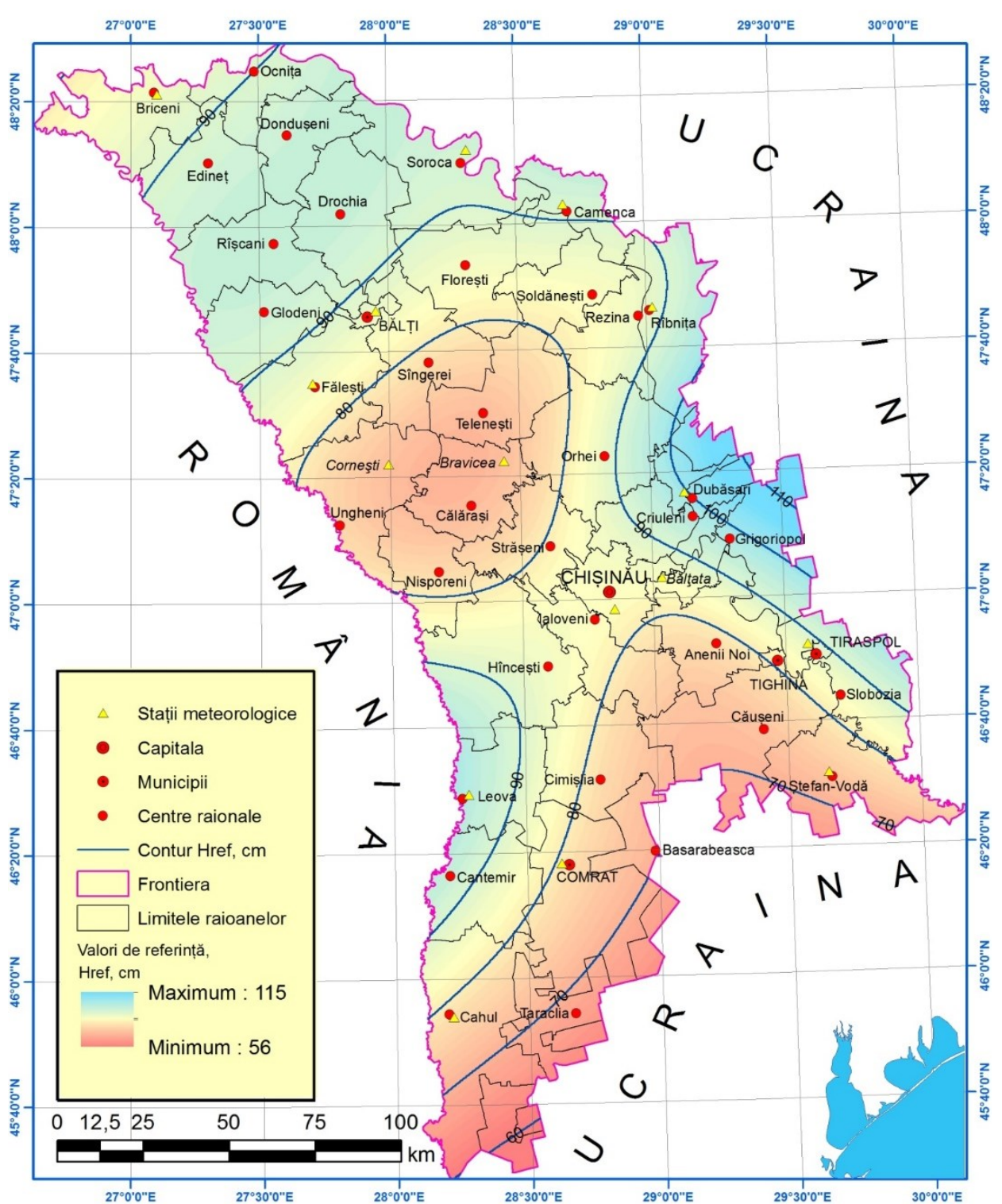

Fig.1. Spatial distribution map of the reference values of the frozen soil's depth with mean return period equal to 50 years 
18 Maria Nedealcov, Valentin Răileanu, Gheorghe Croitoru, Cojocari Rodica, Crivova Olga

Table 1. The reference values of the frozen soil's depth for 58 localities in the Republic of Moldova with an average return period of 50 years $(\mathrm{IMR}=50)$

\begin{tabular}{|c|c|c|c|}
\hline Nr. & Locality & Region/municipality & Href, cm \\
\hline 1 & Anenii Noi & Anenii Noi & 79 \\
\hline 2 & Bălţata* & Mun. Chişinău & 85 \\
\hline 3 & Bălți & Mun. Bălţi & 87 \\
\hline 4 & Bălți* & Mun. Bălţi & 87 \\
\hline 5 & Basarabeasca & Basarabeasca & 71 \\
\hline 6 & Bravicea* & Călăraşi & 73 \\
\hline 7 & Briceni & Briceni & 86 \\
\hline 8 & Briceni* & Briceni & 87 \\
\hline 9 & Cahul & Cahul & 79 \\
\hline 10 & Cahu1* & Cahul & 79 \\
\hline 11 & Călaraşi & Călaraşi & 72 \\
\hline 12 & Camenca & Camenca & 90 \\
\hline 13 & Camenca ${ }^{*}$ & Camenca & 91 \\
\hline 14 & Cantemir & Cantemir & 93 \\
\hline 15 & Căuşeni & Căuşeni & 74 \\
\hline 16 & Ceadîr-Lunga* & Ceadìr-Lunga & 68 \\
\hline 17 & Chişinău & Mun. Chişinău & 84 \\
\hline 18 & Chişinău* & Mun. Chişinău & 84 \\
\hline 19 & Cimişlia & Cimişlia & 78 \\
\hline 20 & Comrat & Mun. Comrat & 79 \\
\hline 21 & Comrat* & Mun. Comrat & 80 \\
\hline 22 & Corneşti* & Ungheni & 73 \\
\hline 23 & Criuleni & Criuleni & 97 \\
\hline 24 & Donduşeni & Donduşeni & 92 \\
\hline 25 & Drochia & Drochia & 93 \\
\hline 26 & Dubăsari & Dubăsari & 99 \\
\hline 27 & Dubăsari* & Dubăsari & 100 \\
\hline 28 & Edineţ & Edineţ & 91 \\
\hline 29 & Făleşti & Făleşti & 85 \\
\hline 30 & Făleşti* & Făleşti & 86 \\
\hline 31 & Floreşti & Floreşti & 86 \\
\hline 32 & Glodeni & Glodeni & 92 \\
\hline
\end{tabular}




\begin{tabular}{|c|c|c|c|}
\hline Nr. & Locality & Region/municipality & Href, cm \\
\hline 33 & Grigoriopol & Grigoriopol & 97 \\
\hline 34 & Hînceşti & Hînceşti & 86 \\
\hline 35 & Ialoveni & Ialoveni & 84 \\
\hline 36 & Leova & Leova & 96 \\
\hline 37 & Leova* & Leova & 96 \\
\hline 38 & Nisporeni & Nisporeni & 77 \\
\hline 39 & Ocniţa & Ocniţa & 90 \\
\hline 40 & Orhei & Orhei & 88 \\
\hline 41 & Rezina & Rezina & 87 \\
\hline 42 & Ríbniţa & Rîbniţa & 88 \\
\hline 43 & Rîbniţą* & Rîbniţa & 89 \\
\hline 44 & Rîscani & Rîscani & 93 \\
\hline 45 & Sîngerei & Sîngerei & 78 \\
\hline 46 & Slobozia & Slobozia & 84 \\
\hline 47 & Şodaneşti & Şodaneşti & 84 \\
\hline 48 & Soroca & Soroca & 91 \\
\hline 49 & Soroca* & Soroca & 92 \\
\hline 50 & Ştefan-Vodă & Ştefan-Vodă & 74 \\
\hline 51 & Ştefan-Vodă* & Ştefan-Vodă & 75 \\
\hline 52 & Străşeni & Străşeni & 81 \\
\hline 53 & Taraclia & Taraclia & 68 \\
\hline 54 & Teleneşti & Teleneş̧i & 73 \\
\hline 55 & Tighina & Mun. Tighina & 82 \\
\hline 56 & Tiraspol & Mun. Tiraspol & 87 \\
\hline 57 & Tiraspol* & Tiraspol & 88 \\
\hline 58 & Ungheni & Ungheni & 77 \\
\hline
\end{tabular}

Note: ${ }^{*}$-meteorological station

Spatial distribution map of the reference values of the thickness of the hoar frost $\boldsymbol{b}, \mathrm{mm}$, with an average return period of 50 years is shown in Fig. 2. $\boldsymbol{b}$, varies within the range of 8.4-29.5. The corresponding values are indicated on the isolines $\boldsymbol{b}$. The highest values are observed in the North and West (in central and southern parts) of the territory. 


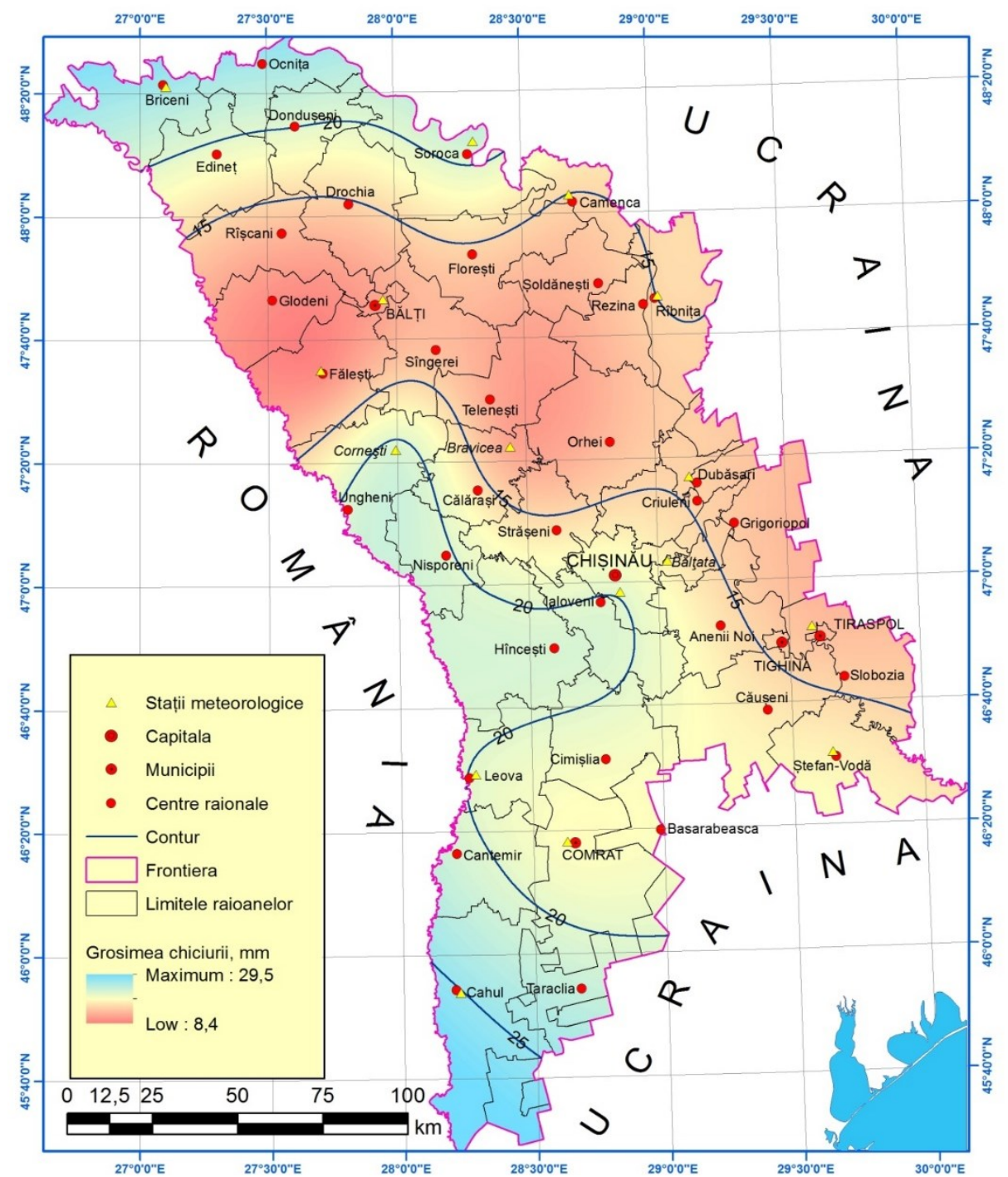

Fig.2. Spatial distribution map of the reference values of the hoar frost's thickness with mean return period equal to 5 years

The reference values of the thickness of the hoar frost may be used to determine the linear load of hoar frost on high voltage power lines and electrical transmission lines using equation (9).

The equation (10) can be used for hoar- frost's surface load. 
Table 2. The reference values of the hoar frost's thickness $b, \mathrm{~mm}$, for for 58 localities from Republic of Moldova (mean return period is equal 5 years)

\begin{tabular}{|c|c|c|c|}
\hline $\mathrm{Nr}$ & Locality & Region/municipality & $b, \mathbf{m m}$ \\
\hline 1 & Anenii Noi & Anenii Noi & 16.1 \\
\hline 2 & Bălţata* & Mun. Chişinău & 16.7 \\
\hline 3 & Bălți & Mun. Bălţi & 11.1 \\
\hline 4 & Bălți* & Mun. Bălţi & 11.5 \\
\hline 5 & Basarabeasca & Basarabeasca & 18.1 \\
\hline 6 & Bravicea* & Călăraşi & 11.4 \\
\hline 7 & Briceni & Briceni & 24.5 \\
\hline 8 & Briceni* & Briceni & 24.3 \\
\hline 9 & Cahul & Cahul & 23.2 \\
\hline 10 & Cahul* & Cahul & 25.1 \\
\hline 11 & Călaraşi & Călaraşi & 16.0 \\
\hline 12 & Camenca & Camenca & 14.6 \\
\hline 13 & Camenca* & Camenca & 14.9 \\
\hline 14 & Cantemir & Cantemir & 21.1 \\
\hline 15 & Căuşeni & Căuşeni & 16.3 \\
\hline 16 & Ceadir-Lunga* & Ceadir-Lunga & 20.1 \\
\hline 17 & Chişinău & Mun. Chişinău & 19.1 \\
\hline 18 & Chişinău* & Mun. Chişinău & 19.8 \\
\hline 19 & Cimişlia & Cimişlia & 18.5 \\
\hline 20 & Comrat & Mun. Comrat & 17.8 \\
\hline 21 & Comrat* & Mun. Comrat & 17.9 \\
\hline 22 & Corneşti* & Ungheni & 20.8 \\
\hline 23 & Criuleni & Criuleni & 14.7 \\
\hline 24 & Donduşeni & Donduşeni & 20.0 \\
\hline 25 & Drochia & Drochia & 14.7 \\
\hline 26 & Dubăsari & Dubăsari & 14.6 \\
\hline 27 & Dubăsari* & Dubăsari & 14.6 \\
\hline 28 & Edineţ & Edineţ & 24.3 \\
\hline 29 & Făleşti & Făleşti & 9.5 \\
\hline
\end{tabular}


22 Maria Nedealcov, Valentin Răileanu, Gheorghe Croitoru, Cojocari Rodica, Crivova Olga

\begin{tabular}{|c|c|c|c|}
\hline Nr. & Locality & Region/municipality & $b, \mathbf{m m}$ \\
\hline 30 & Făleşti* & Făleşti & 9.3 \\
\hline 31 & Floreşti & Floreşti & 14.4 \\
\hline 32 & Glodeni & Glodeni & 9.6 \\
\hline 33 & Grigoriopol & Grigoriopol & 14.1 \\
\hline 34 & Hînceşti & Hînceşti & 20.7 \\
\hline 35 & Ialoveni & Ialoveni & 29.1 \\
\hline 36 & Leova & Leova & 20.0 \\
\hline 37 & Leova* & Leova & 19.8 \\
\hline 38 & Nisporeni & Nisporeni & 20.3 \\
\hline 39 & Ocniţa & Ocniţa & 24.3 \\
\hline 40 & Orhei & Orhei & 13.0 \\
\hline 41 & Rezina & Rezina & 14.6 \\
\hline 42 & Rîbniţa & Rîbniţa & 15.0 \\
\hline 43 & Rîbniţa* & Rîbniţa & 15.0 \\
\hline 44 & Rîscani & Rîscani & 12.8 \\
\hline 45 & Sîngerei & Sîngerei & 13.3 \\
\hline 46 & Slobozia & Slobozia & 14.4 \\
\hline 47 & Şodaneşti & Şodaneşti & 13.3 \\
\hline 48 & Soroca & Soroca & 20.6 \\
\hline 49 & Soroca* & Soroca & 21.5 \\
\hline 50 & Ştefan-Vodă & Ştefan-Vodă & 16.9 \\
\hline 51 & Ştefan-Vodă* & Ştefan-Vodă & 16.8 \\
\hline 52 & Străşeni & Străşeni & 16.0 \\
\hline 53 & Taraclia & Taraclia & 22.0 \\
\hline 54 & Teleneşti & Teleneş̧ti & 11.9 \\
\hline 55 & Tighina & Mun. Tighina & 14.3 \\
\hline 56 & Tiraspol & Mun. Tiraspol & 13.3 \\
\hline 57 & Tiraspo1* & Tiraspol & 13.2 \\
\hline 58 & Ungheni & Ungheni & 20.5 \\
\hline
\end{tabular}

Note: *-meteorologic station 


\section{Conclusions}

The analysis of the annual maximum values of frozen soil's thickness and hoar frost thickness in the Gumbel distribution allowed to obtain the reference values with a certain average return time at each meteorological station.

Reference values can be used to elaborate digital maps, which can be used to obtain the corresponding values for certain localities.

The maps and tables presented in the work can be used for the elaboration of normative documents in constructions for the Republic of Moldova.

\section{References}

1. *** (1977) STAS 6054/77 Romanian standard

2. *** (2016) СП 20.13330.2016 Нагрузки и воздействия. https://steeldevelopment.ru/upload/iblock/ 19f/19f628034d170f73f6e97e411abc046f.pdf (accessed 09.11.2017)

3. $* * *$ (2006) ДБН В.1.2-2:2006. Нагрузки и воздействия. https:/www.promdesign.ua/assets/files/\%20B.1.2-2-2006.pdf. ） (accessed 09.11.2017)

4. ${ }^{* * *}$ http://www.mathwave.com/articles/extreme-value-distributions.html. (accessed 22.11.2017)

5. *** Engineering Statistics Handbook 1.3.6.6.16. Extreme Value Type I Distribution. http://www.itl.nist.gov/div898/handbook/eda/section3/eda366g.htm. (accessed 23.11.2017)

6. *** (2004) Normativ pentru construcția liniilor aeriene de energie electrică cu $\begin{array}{lllll}\text { tensiuni } \quad 1000 & \text { p } & \text { NTE } & 03 / 04 / 00 .\end{array}$ https://stoianconstantin.files.wordpress.com/2012/09/17_nte-0030400-pe-104.doc (accessed 17.11.2017) 